\title{
Dual function of the McaS small RNA in controlling biofilm formation
}

\author{
Mikkel Girke Jørgensen, ${ }^{1,4}$ Maureen K. Thomason, ${ }^{2,3,4}$ Johannes Havelund, ${ }^{1}$ Poul Valentin-Hansen, ${ }^{1,5}$ \\ and Gisela Storz ${ }^{2,5}$ \\ ${ }^{1}$ Department of Biochemistry and Molecular Biology, University of Southern Denmark, DK-5230 Odense, Denmark; ${ }^{2}$ Cell \\ Biology and Metabolism Program, Eunice Kennedy Shriver National Institute of Child Health and Human Development, \\ Bethesda, Maryland 20892, USA; ${ }^{3}$ Department of Biochemistry and Molecular and Cellular Biology, Georgetown University \\ Medical Center, Washington, DC 20007, USA
}

\begin{abstract}
Many bacterial small RNAs (sRNAs) regulate gene expression through base-pairing with mRNAs, and it has been assumed that these sRNAs act solely by this one mechanism. Here we report that the multicellular adhesive (McaS) sRNA of Escherichia coli uniquely acts by two different mechanisms: base-pairing and protein titration. Previous work established that McaS base pairs with the mRNAs encoding master transcription regulators of curli and flagella synthesis, respectively, resulting in down-regulation and up-regulation of these important cell surface structures. In this study, we demonstrate that McaS activates synthesis of the exopolysaccharide $\beta-1,6 \mathrm{~N}$-acetylD-glucosamine (PGA) by binding the global RNA-binding protein CsrA, a negative regulator of pgaA translation. The McaS RNA bears at least two CsrA-binding sequences, and inactivation of these sites compromises CsrA binding, PGA regulation, and biofilm formation. Moreover, ectopic McaS expression leads to induction of two additional CsrA-repressed genes encoding diguanylate cyclases. Collectively, our study shows that McaS is a dualfunction sRNA with roles in the two major post-transcriptional regulons controlled by the RNA-binding proteins Hfq and CsrA.
\end{abstract}

[Keywords: Hfq; CsrA; CsrB; PGA; c-di-GMP]

Supplemental material is available for this article.

Received January 25, 2013; revised version accepted April 10, 2013.

In the last decade, it has become apparent that posttranscriptional regulation of gene expression plays an important role in controlling many different physiological processes. In bacteria, key mediators of this post transcriptional response are small RNAs (sRNAs) (for review, see Storz et al. 2011). Most of the characterized sRNA regulators act by base-pairing with trans-encoded mRNAs, frequently a regulon of targets, at or near ribosome-binding sites to block or activate translation or modulate mRNA stability. In enteric bacteria, many of the sRNAs that act in this manner have limited complementarity with the mRNA target and require the Sm-like RNA chaperone protein Hfq for base-pairing. Other characterized sRNAs bind to proteins and modulate their activities. A few base-pairing sRNAs also have been found to have the additional function of encoding a small protein (for review, see Vanderpool et al. 2011).

\footnotetext{
${ }^{4}$ These authors contributed equally to this work.

${ }^{5}$ Corresponding authors

E-mail storzg@mail.nih.gov

E-mail valentin@bmb.sdu.dk

Article published online ahead of print. Article and publication date are online at http://www.genesdev.org/cgi/doi/10.1101/gad.214734.113.
}

Hfq-binding sRNAs play a prominent role in the regulation of biofilm formation in Escherichia coli, which requires accurate temporal and spatial expression of flagella, curli fibers, and the exopolysaccharides colanic acid, cellulose, and poly- $\beta-1,6 \mathrm{~N}$-acetyl-D-glucosamine (PGA) (for review, see Flemming and Wingender 2010; López et al. 2010). Multiple base-pairing sRNAs have already been shown to modulate expression of critical transcription regulators of these extracellular structures. FlhD, the master regulator of flagellar synthesis, is a hub for sRNAmediated regulation, as the $5^{\prime}$ untranslated region (UTR) of the flhDC mRNA is targeted for repression by four sRNAs (ArcZ, OmrA, OmrB, and OxyS) and for activation by one sRNA (multicellular adhesive [McaS]) (De Lay and Gottesman 2012; Thomason et al. 2012). CsgD, the master transcription regulator of curli biogenesis, similarly is under the control of multiple sRNAs (OmrA, OmrB, McaS, RprA, and GcvB). At least four of these sRNAs base-pair directly with the $\operatorname{csg} D 5^{\prime}$ UTR, resulting in reduced CsgD protein synthesis and degradation of the $\operatorname{csg} D$ transcript (Holmqvist et al. 2010; Jørgensen et al. 2012; Mika et al. 2012; Thomason et al. 2012). Additionally, the pgaABCD operon encoding the enzymes and porin required for the synthesis and secretion of the exopolysaccharide PGA was 
shown to be positively regulated by the McaS RNA, although it was not known whether this effect is direct or indirect (Thomason et al. 2012).

The RNA-binding protein CsrA also has been implicated in the post-transcriptional control of biofilm formation. CsrA is a 61-amino-acid protein that functions as a homodimer to bind specific motifs in the UTRs of a number of mRNAs to either negatively or positively affect processes such as carbon metabolism, flagellar synthesis, and biofilm formation (for review, see Romeo et al. 2012). Each CsrA dimer contains two positively charged RNAbinding pockets that preferentially bind GGA motifs present in the loop regions of short hairpin structures (Dubey et al. 2005; Mercante et al. 2006; Schubert et al. 2007). This architecture allows for the binding of one CsrA dimer to two binding motifs or, in some cases, the binding of multiple CsrA dimers to several motifs in an mRNA (Schubert et al. 2007; Mercante et al. 2009). The regulation of mRNAs by CsrA is antagonized by the action of two Hfq-independent sRNAs, CsrB (Liu et al. 1997) and CsrC (Weilbacher et al. 2003), which contain 18 and nine GGA motifs, respectively, that bind and sequester CsrA, blocking its ability to regulate target mRNAs.

CsrA-mediated control of biofilm formation occurs through repression of a number of mRNA targets. For example, CsrA represses pgaA directly by binding to six sites in the pgaA 5' UTR (Wang et al. 2005) and indirectly by repressing the synthesis of NhaR, a transcription activator of the pgaABCD operon (Pannuri et al. 2012). CsrA also indirectly regulates biofilm formation by binding to and repressing translation of the mRNAs encoding a number of diguanylate cyclases, including YcdT and YdeH. These enzymes have been shown to regulate motility and biofilm formation as well as PgaD expression at the posttranscriptional level by altering cyclic di-GMP (c-diGMP) levels (Jonas et al. 2008; Boehm et al. 2009; Steiner et al. 2013). CsrA also binds the flhD 5' UTR and activates expression of this transcription regulator through protection from cleavage by RNase E (Yakhnin et al. 2013). Additional CsrA-mediated effects on biofilm formation might be due to observed CsrA repression of Hfq expression (Baker et al. 2007), which could alter the stabilities of sRNA regulators of biofilm formation.

In this study, we provide evidence that activation of pgaA by McaS is indirect through titration of CsrA, which results in relief of the pgaA mRNA repression. McaS binds tightly to CsrA in coimmunoprecipitation assays and gel mobility shift assays through two GGA motifs located in McaS stem-loops. Mutants with decreased or increased CsrA binding also had the expected effects on the expression of the CsrA-controlled YcdT and $\mathrm{YdeH}$ diguanylate cyclases as well as on the synthesis and export of the exopolysaccharide PGA. In addition, chromosomal expression of McaS mutants defective in CsrA binding resulted in defects in biofilm formation. The Hfq-binding McaS is the first example of a novel class of dual-function sRNA that acts directly by basepairing to the $5^{\prime}$ UTRs of $\operatorname{csg} D$ and $f l h D$ and indirectly by sequestering a global post-transcriptional regulatory protein.

\section{Results}

McaS-dependent regulation is retained in truncations of the pgaA 5' UTR

Previous work demonstrated that the McaS sRNA activates pgaA expression (Thomason et al. 2012). Multiple sites of potential base-pairing were predicted between McaS and the pgaA leader. In some cases, mutations of the McaS sequences predicted to be involved in basepairing (for example, McaS-2) disrupted activation as predicted, but in one case (McaS-3), the mutations unexpectedly resulted in increased activation of a $\mathrm{pgaA}$ lacZ fusion (see Fig. 2B [below] for sequence of mutations). In addition, no single compensatory mutation or even double and triple combinations of compensatory mutations introduced into the pgaA leader restored McaSdependent activation for defective mutants (Thomason et al. 2012; data not shown).

Given these results, we set out to delineate the region within the 234-nucleotide (nt) pgaA leader that might be responsible for McaS-dependent activation by creating a series of $5^{\prime}$ UTR truncations (Fig. 1A). Progressively shorter regions of the pgaA 5' UTR through the first 10 codons of the ORF were fused in-frame to lac $Z$ under the control of the $\mathrm{P}_{\mathrm{BAD}}$ promoter on the chromosome (Fig. 1A; Mandin and Gottesman 2009). A deletion of the $a b g R$-mcaS-ydaL region $(\Delta a b g R$-ydaL) (Thomason et al. 2012) was also moved into these strain backgrounds to eliminate chromosomal McaS expression.

As shown in Figure 1B, when McaS expression was induced from pBR-McaS with $1 \mathrm{mM}$ IPTG, the full-length pgaA $A_{234}$-lac $Z$ fusion was activated $\sim 15$-fold compared with the vector control strain. As observed previously (Thomason et al. 2012), expression of the McaS-2 mutant gave no activation of the pgaA $A_{234}-1 a c Z$ fusion, while expression of McaS-3 resulted in hyperactivation of the pgaA $A_{234}$-lacZ fusion $\sim 60$-fold compared with the vector control strain and approximately fourfold compared with the pBR-McaS strain. Interestingly, each of the other pgaA-lacZ fusions showed similar patterns of activation (Figs. 1 B-D; Supplemental Fig. 1). In each truncation fusion, expression from pBR-McaS resulted in approximately fivefold to 11-fold activation, depending on the pgaA-lacZ fusion. Similar to what we observed for fulllength $\mathrm{pgaA}_{234}-\mathrm{lacZ}$, expression of McaS-2 gave no activation of the truncation fusions, while expression of McaS-3 resulted in hyperactivation of the fusions $(\sim 13$ fold to 44-fold). No base-pairing of longer than five consecutive nucleotides was predicted between McaS and the pgaA sequence present in the shortest fusion, $p_{3 a} A_{30}-1 a c Z$, yet the fusion was still activated by McaS. This led us to conclude that activation of $\mathrm{pgaA}$ by McaS is not via direct base-pairing but rather must be indirect via a different mechanism.

\section{McaS activation of pgaA-lacZ is dependent on CsrA}

CsrA is known to bind six places within the 5' UTR of pgaA to repress translation of the mRNA (Fig. 1A; Wang et al. 2005). With the $p g a A_{155}, p g a A_{67}$, and $p g a A_{30}$ 
truncations, known CsrA-binding sites within the pgaA leader were removed, and the overall basal activity of the fusions increased. Nevertheless the $\mathrm{pgaA}_{30}$ truncation still retained two CsrA-binding sites. We previ-

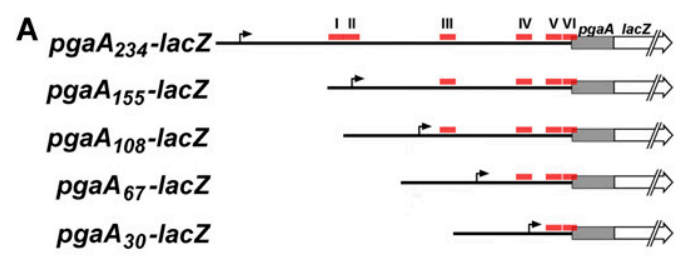

B

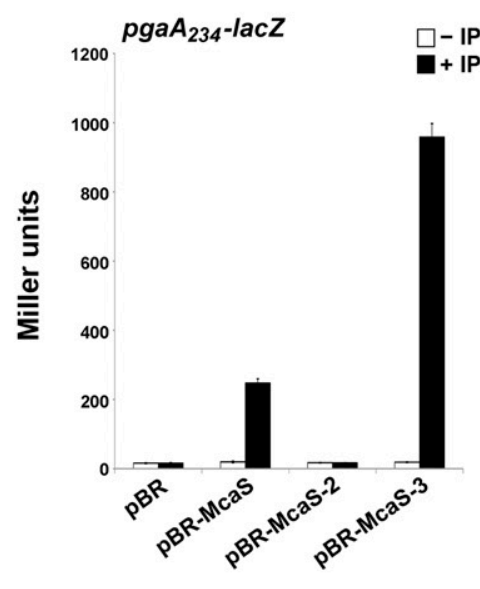

C

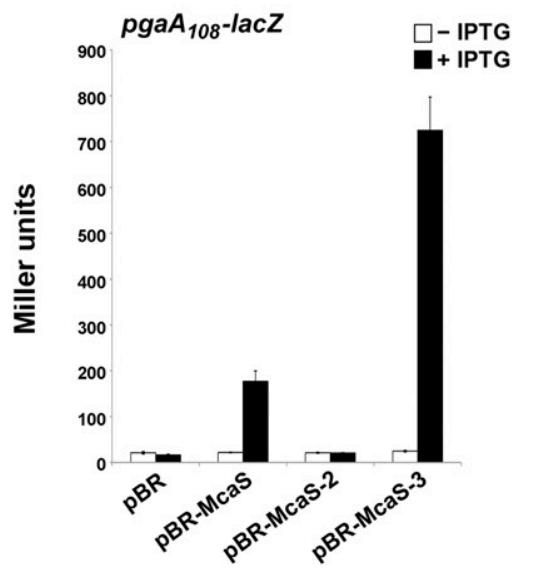

D

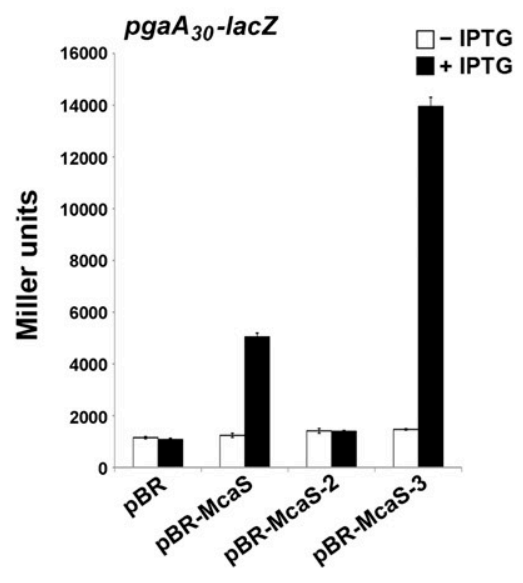

ously noted (Thomason et al. 2012) that McaS contains multiple GGA sequence elements that could be bound by CsrA (Fig. 2A). We thus hypothesized that McaS might be activating pgaA expression indirectly by titrating CsrA away from the mRNA.

To test whether McaS is acting through CsrA, we examined the effects of McaS and the McaS-2 and McaS-3 mutant forms on pgaA expression in the presence and absence of fully functional CsrA. A $\Delta p g a A:: c a t$ mutation was first introduced into the $\mathrm{pgaA}_{234}-1 a c Z$ $\Delta a b g R-y d a L$ strain background to eliminate the autoaggregation phenotype associated with reduced CsrA repression of the pgaABCD locus (Jin et al. 2009). The TR1-5 $\operatorname{csr} A::$ kan allele was then transduced into this background to generate a strain in which the activity of CsrA is reduced due to a transposon insertion in the $\operatorname{csr} A$ ORF (Romeo et al. 1993; Timmermans and Van Melderen 2009). The overall levels of the pgaA-lacZ fusion were elevated in the $\operatorname{csr} A::$ kan mutant background, consistent with the loss of the tight CsrA repression of pgaA (Wang et al. 2005). When McaS expression was induced from pBR-McaS, activation of the pgaA-lacZ fusion was limited to only approximately threefold in the $\operatorname{csr} A:: \mathrm{kan}$ background compared with $\sim 17$-fold in the corresponding wild-type strain (Fig. 2C). The mild activation of the pgaA-lacZ fusion by McaS in the $\operatorname{csr} A::$ kan mutant strain may result from the partial CsrA activity retained by the mutant (Timmermans and Van Melderen 2009). The McaS-2 mutant showed no activation of pgaA-lacZ in either the presence or absence of fully functional CsrA. Interestingly, the hyperactive McaS-3 mutant showed the same level of activation as wild-type McaS in the $\operatorname{csr} A::$ kan background, approximately threefold, indicating that the advantage provided by the McaS-3 mutation was lost without fully functional CsrA.

We also looked at the ability of two other sRNAs to activate pgaA-lacZ: CsrB, shown in many studies to bind CsrA and modulate its function (for review, see Romeo et al. 2012), and GcvB, previously reported to coimmunoprecipitate with CsrA (Edwards et al. 2011). As expected, CsrB was able to activate the pgaA-lacZ fusion $\sim 58$-fold in the wild-type background but only approximately fivefold in the csrA::kan mutant (Fig. 2C). GcvB, however, was

Figure 1. Truncations of the pgaA 5' UTR do not eliminate McaS-dependent regulation. (A) Schematic representation of pgaA-lacZ truncation fusions. Each translational fusion contains the portion of the pgaA 5' UTR indicated by the arrow as well as the first 10 codons ( $30 \mathrm{nt}$ ) of the pgaA ORF fused inframe to lacZ on the chromosome. The red boxes indicate potential CsrA-binding sites. $(B-D)$ Assays of PM1205 $\Delta a b g R$ $y d a L$ derivatives with the indicated pgaA-lacZ fusions transformed with the control vector, pBR-McaS, and plasmids expressing the McaS-2 and McaS-3 mutant derivatives. $\beta$-Galactosidase activities of the fusions were assayed with either $1 \mathrm{mM}$ IPTG (black bars) or no IPTG (white bars). The average values from three independent assays are shown, and error bars are standard deviations of those values. The data for the other two truncations represented in $A$ are given in Supplemental Figure S1. 


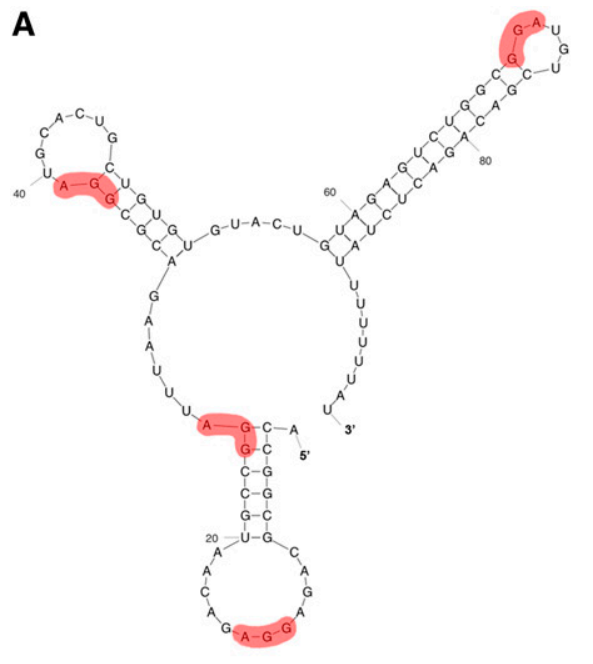

B

\begin{tabular}{|c|c|}
\hline cas & $\begin{array}{l}20 \\
5^{\prime} \\
\text { ACCGGCGCAGAGGAGACAUGCCGGAUUUAAGACGCGGAUGCACUGCUGU }\end{array}$ \\
\hline ca & CGGCGCAGAGGUUCAAUGCCGGAUUUAAC \\
\hline 3 & ACCGGCGCAGAGGAGACAAUGCCGGAUUUAAGUGACGGAUGCACUC \\
\hline & GAGGUC \\
\hline & AAGUGACGGE \\
\hline & IAAGUGACGGAUGCA \\
\hline & $c \mathrm{C}$ \\
\hline
\end{tabular}

C

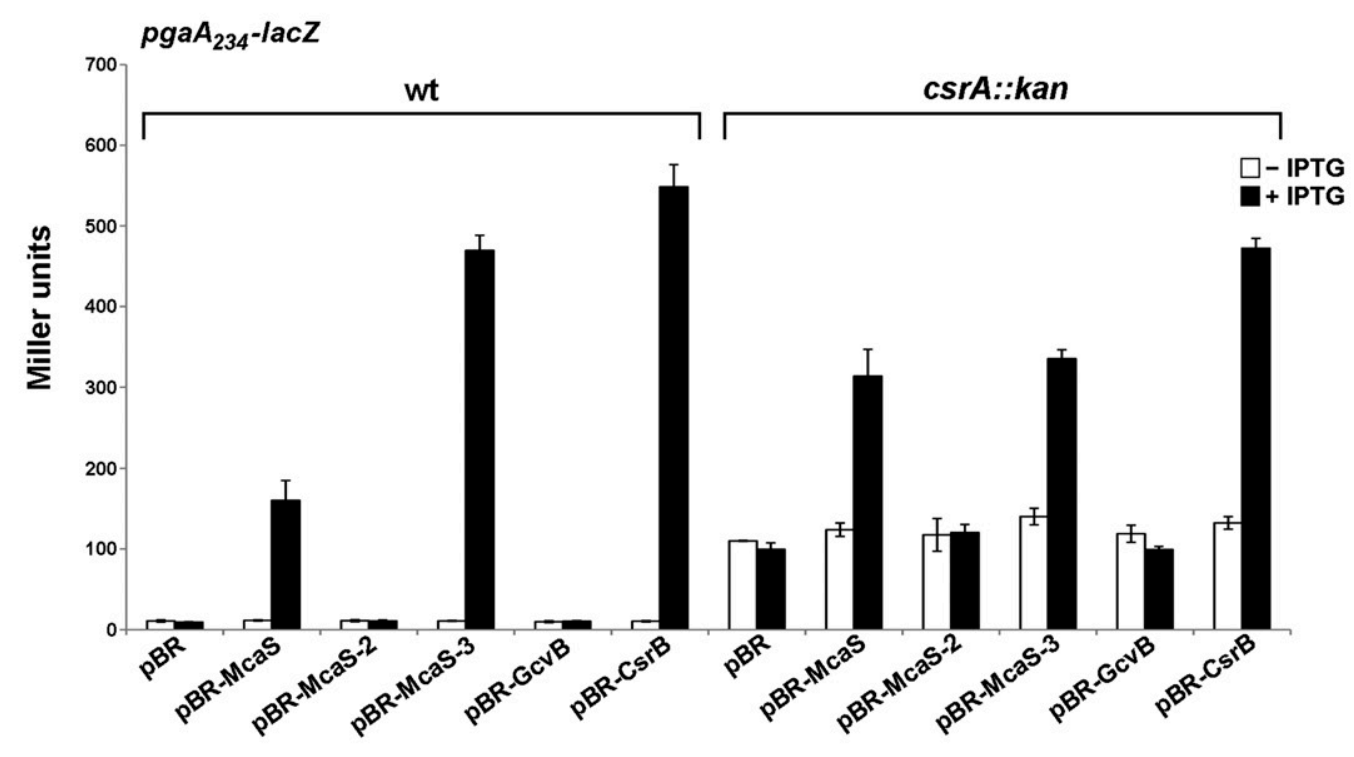

D

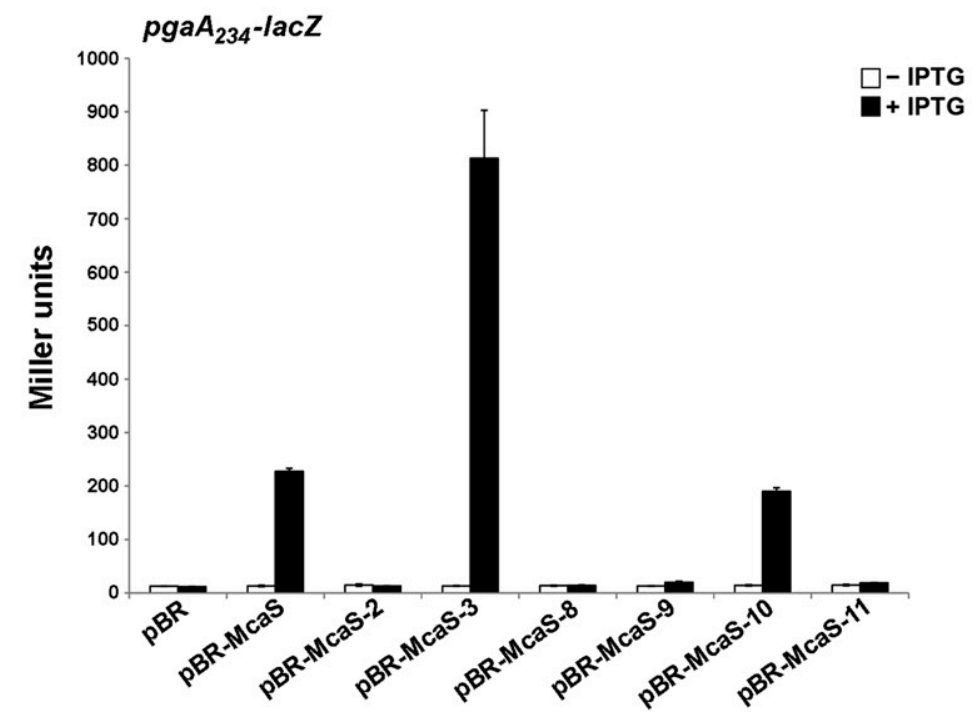

Figure 2. CsrA dependence of McaS-mediated effects on pgaA-lacZ expression. (A) Predicted structure of wild-type McaS showing putative CsrA-binding sites (highlighted in red). (B) The sequences of the first $50 \mathrm{nt}$ of wild-type McaS and mutant derivatives. Nucleotides altered for each mutant are boxed. Putative CsrA-binding sites are shaded in red. (C) McaS-dependent activation of pgaA$l a c Z$ expression requires functional CsrA. The reporter stains PM1205 $\Delta a b g R-y d a L \Delta p g a A:: c a t$ pgaA $234-1 a c Z$ and PM1205 $\Delta a b g R-y d a L$ $\Delta$ pgaA ::cat csrA::kan pgaA $234-1 a c Z$ were transformed with the control vector, pBR-McaS, pBR-McaS-2, pBR-McaS-3, pBR-GcvB, and pBR-CsrB. $(D)$ McaS mutants carrying disrupted GGA motifs do not activate pgaA-lacZ expression. The reporter strain PM1205 $\Delta a b g R$ ydaL pgaA $A_{234^{-}}$lacZ was transformed with the control vector, pBR-McaS, and plasmids expressing McaS mutant derivatives. $\beta$-Galactosidase activity in $C$ and $D$ was assayed as in Figure 1. 
unable to activate expression of $p g a A-l a c Z$ in either the presence or absence of fully functional CsrA (Fig. 2C). This indicates that while a number of base-pairing sRNAs contain GGA motifs, these RNA molecules may not be sufficiently abundant or able to bind sufficiently tightly to alter the activity of CsrA.

\section{McaS activation of pgaA-lacZ is dependent on at least two CsrA-binding sites}

Examining the conservation of McaS across a number of closely related species indicated that two of the four putative GGA CsrA-binding motifs found in McaS are completely conserved (Supplemental Fig. S2)—specifically the motifs present in the $5^{\prime}$ and central stem-loops. The mcaS-2 mutation, which prevents pgaA-lacZ activation (Figs. 1B, 2C), alters the potential CsrA-binding site in the 5' loop of McaS (Fig. 2A,B). We hypothesized that the mcaS-3 mutation, which gives rise to hyperactivation of pgaA-lacZ (Figs. 1B, 2C), may increase the accessibility of CsrA for the central GGA-binding site by disrupting the second stem (Fig. 2A,B). Our previous work showed that mutating the less conserved GGA motif in the terminator stem (McaS-4) only marginally effected pgaA-lacZ activation (approximately twofold compared with wild-type McaS) (Thomason et al. 2012). These results led us to hypothesize that the GGA motifs found in the $5^{\prime}$ and central stemloops of McaS might be required for CsrA binding to McaS and, consequently, activation of pgaA-lacZ expression.

To test the hypothesis that there are CsrA-binding sites in the $5^{\prime}$ and central stem-loops of McaS and examine the contributions of each of these predicted binding sites, we systematically mutated the McaS sequence, introducing various combinations of mutations within the GGA motifs (Fig. 2B). Similar to the mcaS-2 mutation, no $\mathrm{ggaA}_{234-1 a c Z}$ activation was observed when A14 of the GGA motif in the $5^{\prime}$ stem-loop was mutated to a U nucleotide (McaS-8) (Fig. 2D). However, this mutant was still able to regulate the two other known targets of McaS ( $\operatorname{csg} D$ and flhD), indicating that McaS-8 is still a functional base-pairing sRNA (Supplemental Fig. S3). Likewise, an A39U mutation in the GGA motif of the central stem-loop (McaS-9) eliminated activation of the $p g a A-l a c Z$ fusion in the context of the mcaS-3 mutation (Fig. 2D), although this mutant also was still able to regulate $\operatorname{csg} D$ and $f 1 h D$ (Supplemental Fig. S3). When the central stem-loop GGA is mutated by an A39U substitution (McaS-11), in the wild-type context, there also is no activation of pgaA-lacZ expression (Fig. 2D). Surprisingly, however, when the A14 residue in the $5^{\prime}$ stem-loop GGA motif is mutated but there is increased access to GGA in the central stem-loop (McaS-10), we still observed $\sim 15$-fold activation of $\mathrm{pgaA}$ lacZ compared with $\sim 19$-fold activation by wild-type McaS (Fig. 2D). These results indicate that even when the 5' stem-loop GGA motif is mutated, the presence of the GGA motif in the central stem is sufficient to partially activate $p g a A-l a c Z$ expression, provided there is increased accessibility to the central stem-loop.

We note that most of the mutant variants were expressed at somewhat lower levels than wild-type
McaS when expression was induced with $1 \mathrm{mM}$ IPTG (Supplemental Fig. S4A). Nevertheless, when expression of wild-type McaS and the McaS-3 and McaS-10 mutants was reduced to match the lower levels of the variants that did not stimulate pgaA-lacZ expression (McaS-2, McaS-8, and McaS-11), we still observed approximately threefold activation of the pgaA-lacZ fusion (Supplemental Fig. S4B,C). These results demonstrate that the failure to regulate the pgaA-lacZ fusion by the McaS-2, McaS-8, and McaS-11 mutants does not result from the lower levels of the mutants. Rather, our mutational analyses indicate that the $5^{\prime}$ and central stem-loop GGA motifs are required for McaS-mediated activation of pgaA-lacZ expression, presumably through binding and titration of CsrA.

\section{McaS copurifies with CsrA}

To determine whether CsrA binds McaS in vivo, we examined which sRNAs copurify with CsrA. To this end, we generated a derivative of strain SØ928 in which the chromosomal csrA gene was replaced by csrA-Flag encoding a C-terminally Flag-tagged CsrA protein. The Flag-tagged CsrA protein is functional, as it was still able to repress pgaA expression based on colony color on Congo red plates (data not shown). Purifications were carried out with cell extracts prepared from a wild-type control strain and the csrA-Flag strain grown to stationary phase in Luria-Bertani (LB) medium. The extracts were incubated with anti-Flag M2-agarose beads, and proteins were eluted from the beads. The RNA present in the bound fraction as well as the unbound and wash fractions was isolated and examined by Northern analysis. With the exception of the highly abundant 5S RNA, none of the sRNAs tested showed nonspecific binding to anti-Flag beads (Fig. 3, left). For the csrA-Flag extracts,

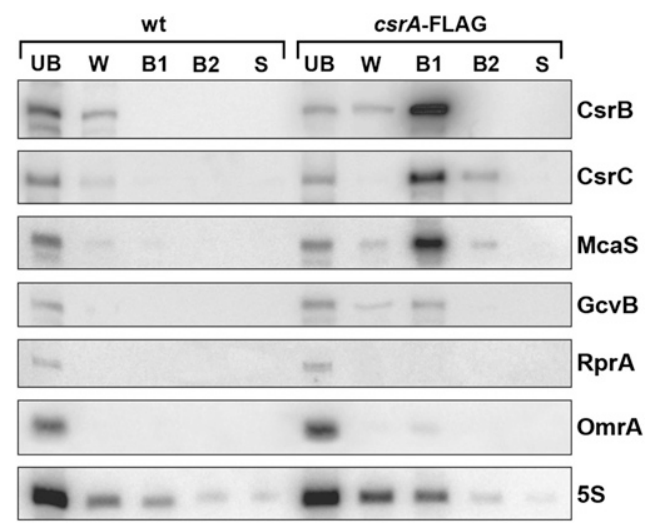

Figure 3. Copurification of CsrA and sRNAs. Cell extracts of strains SØ928 (wt) and SØ928 csrA-Flag were incubated with anti-Flag M2-agarose beads. The beads were collected on a small column, the filtrate was collected (unbound fraction [UB]), and the beads were washed with immunoprecipitation buffer (wash fraction [W]). Subsequently, the proteins trapped on the beads were eluted with $1 \mathrm{M}$ arginine buffer (bound fraction 1 and 2 [B1 and B2]). Total RNA was extracted from all fractions as well as from the beads after the arginine treatment (stripped fraction [S]) and examined for the presence of CsrB, CsrC, McaS, GcvB, RprA, OmrA, and 5S RNA by Northern blot analysis. 
CsrB, CsrC, and McaS were strongly enriched in the bound fraction (Fig. 3, right). In accordance with previous work, some GcvB RNA also was detected in the affinitypurified CsrA-Flag sample (Edwards et al. 2011). Furthermore, we observed minor enrichment for the OmrA RNA, which possesses a terminator loop GGAUG sequence with a reasonable match to the CsrA consensus binding site. In contrast, the RprA and RyhB RNAs, which carry one and two potential binding sites for CsrA, respectively, did not copurify with CsrA-Flag (Fig. 3; Supplemental Fig. S5). The copurification studies suggest that McaS has the ability to bind CsrA and form stable complexes with the post-transcriptional regulator.

\section{Purified CsrA binds Mcas}

To verify the results of the in vivo experiments, we purified CsrA-Flag and treated the purified protein with RNase A to eliminate all copurifying RNA. The RNA-free CsrA-Flag protein was then tested for binding to in vitro synthesized wild-type and mutant McaS RNAs. Samples containing a fixed amount of $5^{\prime}$ end-labeled sRNA were incubated with increasing amounts of purified CsrA-Flag, and complex formation was examined in gel retardation assays. As seen in Figure 4A for wild-type McaS, a single, retarded complex is observed at low concentrations of CsrA, giving an apparent $\mathrm{K}_{\mathrm{d}}$ of $0.7-1 \mathrm{nM}$, similar to the apparent $\mathrm{K}_{\mathrm{d}}$ reported for CsrB (Weilbacher et al. 2003). This complex is shifted to a slower-migrating retarded complex at the expense of the faster-migrating complex with the addition of higher amounts of CsrA. In accordance with the ability of the McaS-3 mutant to hyperactivate pgaA expression, this derivative exhibited higher affinity to CsrA than wildtype McaS. Likewise, the ability of the McaS-10 derivative to partially activate pgaA expression is reflected in its increased binding to CsrA, although it is somewhat less than the hyperactive McaS-3 mutant. Furthermore, it is noteworthy that the McaS-3 and McaS-10 derivatives form just a single retarded complex corresponding to the slowermigrating CsrA-wild-type McaS complex. In contrast, but in keeping with the in vivo data, the binding studies showed that the McaS-2 and McaS-11 mutations significantly compromised CsrA binding. Binding to McaS-8 and McaS-9 also was affected in that a smear of bands was observed for McaS-8, and the slower-migrating band was not detected for McaS-9.

We did not detect complex formation between CsrA and the other Hfq-dependent sRNAs, GcvB and RprA (Fig. $4 \mathrm{~B})$. Finally, our binding studies show that formation of the slow-migrating as well as the fast-migrating CsrAMcaS complexes was challenged by the addition of excess, unlabeled CsrB RNA (Fig. 4C). Overall, the binding data correlate with the regulatory studies presented in Figures 1 and 2, leading us to conclude that CsrA binds specifically to the McaS sRNA.

Mcas modulates expression of other mRNAs that are strongly regulated by CsrA

CsrA is known to strongly repress translation of the $y d e H$ and $y c d T$ mRNAs encoding diguanylate cyclases (Jonas
A
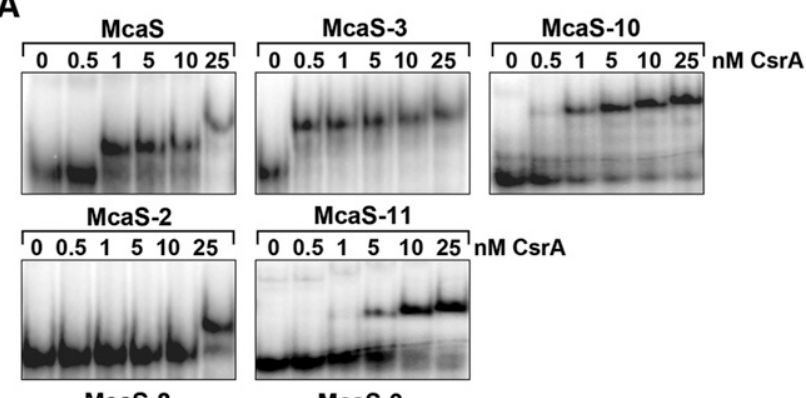

McaS-11

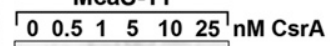

McaS-8

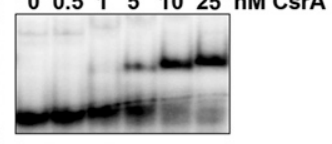

McaS-9
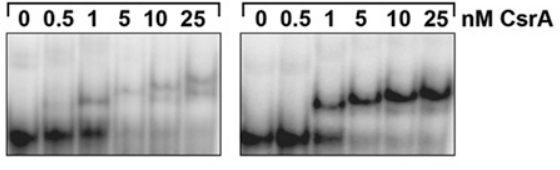

B

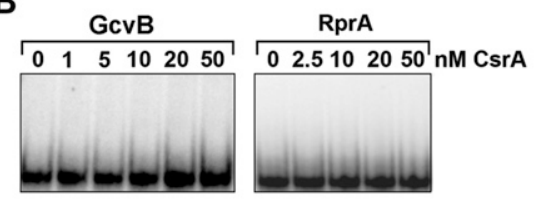

C

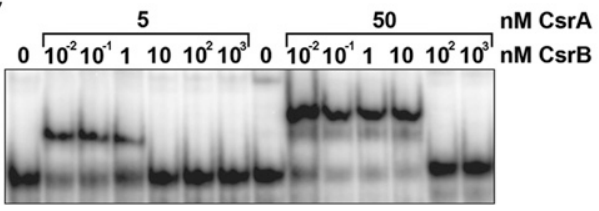

Figure 4. Gel mobility shift assays of purified CsrA binding to sRNAs. (A) Samples containing 5' end-labeled wild-type or mutant McaS RNA (0.25 nM) were incubated with increasing amounts of CsrA protein (at the indicated concentrations). (B) Gel mobility shift assays of CsrA binding to GevB and RprA RNA carried out as in $A$. $(C)$ CsrB competition with McaS for binding to CsrA. Samples containing a fixed concentration of labeled Mcas RNA (1 nM) and either $5 \mathrm{nM}$ or $50 \mathrm{nM}$ CsrA protein were incubated with the indicated concentrations of unlabeled CsrB RNA.

et al. 2008). Expression of PgaD, encoded by the last gene in the pgaABCD operon, was previously found to be regulated by c-di-GMP through activation of the diguanylate cyclase YdeH (Boehm et al. 2009). Additionally, more recent studies have shown that c-di-GMP binds to PgaC and PgaD, stabilizing their interaction and stimulating their activity, and a $\operatorname{csr} A:: \operatorname{Tn} 5$ strain deleted for both $y d e H$ and $y c d T$ has reduced biofilm formation compared with the control csrA mutant strain (Steiner et al. 2013). We thus sought to determine whether McaS also was able to titrate CsrA from the $y d e H$ and ycdT transcripts as well as another known CsrA target, $g \operatorname{lgC}$. For this experiment, we constructed chromosomal ydeH-lacZ, ycdT$1 a c Z$, and $g \operatorname{lgC}-1 a c Z$ translational fusions using the transcription start sites published in EcoCyc (Keseler et al. 2011). As a control, we constructed a chromosomal translational fusion to the $5^{\prime}$ UTR of the ydaM gene, encoding another diguanylate cyclase, which modulates curlimediated biofilm formation and is regulated by the RprA sRNA (Mika et al. 2012) but is not known to be regulated 
by CsrA. The transcription start site for ydaM has not been reported, but we determined the +1 to be $75 \mathrm{nt}$ upstream of the start codon based on global transcription start site mapping (MK Thomason, unpubl.). We again moved the $\Delta a b g R$-ydaL mutation into each strain background to eliminate chromosomal McaS expression. Each strain was transformed with $\mathrm{pBR}$ plasmids expressing wildtype McaS, the hyperactive CsrA-binding mutant McaS-3, the compromised CsrA-binding mutant McaS-8, or pBRCsrB as a positive control.

We did not observe any significant effects of wild-type McaS, the McaS mutant derivatives, or CsrB on expression of the $y$ daM-lac $Z$ fusion, consistent with the lack of known CsrA regulation of the mRNA (Fig. 5A). In contrast, wild-type McaS activated expression of ydeHlac $Z$ by approximately eightfold relative to the control vector, while McaS-3 activated the $y d e H-l a c Z$ fusion by $\sim 25$-fold compared with the vector control (Fig. 5B). McaS-8, which is compromised for CsrA binding and $p g a A$ activation, showed no activity toward the ydeH-lacZ fusion. As expected, CsrB strongly activated expression of this fusion. Similar patterns were observed for the ycdT-lacZ and glgC-lacZ fusions (Fig. 5C; Supplemental Fig. S6). Taken together, these results indicate that McaS is able to relieve CsrA-mediated repression of the ydeH, $y c d T$, and $g \lg C$ mRNAs, resulting in increased activation of these genes, ultimately leading to increased c-di-GMP levels, biofilm formation, and glycogen accumulation.

\section{McaS sequestration of CsrA affects PGA synthesis}

To assay the effects of McaS on the pgaABCD operon more directly, we examined the ability of wild-type and mutant McaS to stimulate PGA production by monitoring colony color on Congo red plates (Izano et al. 2008). These experiments were carried out in an $\Delta r p o S$ strain background to ensure that Congo red binding reflected the synthesis of PGA rather than curli fibers, which are known to be expressed in a $\sigma^{\mathrm{S}}$-dependent manner (Hammar et al. 1995). The cells also were plated on high salt concentrations previously shown to induce pgaABCD expression (Amini et al. 2009). An $\Delta r p o S \Delta$ mcas mutant strain carrying the low-copy-number plasmid pNDM expressing wild-type or mutant McaS (Jørgensen et al. 2012) was plated on Congo red plates in the presence of $5 \mu \mathrm{M}$ IPTG so that McaS was only weakly expressed (Fig. 6A). Cells expressing wild-type McaS were red, indicating Congo red binding. The phenotype was dependent on PGA production and export, as wild-type McaS did not induce Congo red binding in a $\Delta p g a A$ strain. The strains expressing McaS mutants showed phenotypes consistent with the in vitro binding of McaS to CsrA and the lacZ fusion assays. The McaS-8 mutant, compromised for CsrA binding and pgaAlac $Z$ activation, showed little Congo red binding, even when fully induced with $1 \mathrm{mM}$ IPTG (data not shown), while the McaS-3 mutant hyperactive for CsrA binding and pgaA-lac Z activation showed clear Congo red binding. These results indicate that low levels of McaS expression impact expression of the pgaABCD operon and alter the ability of cells to produce PGA.
To further evaluate the effects of McaS on PGA synthesis and secretion, we also assayed the PGA levels present on cells using antibodies raised against Staphylococcus polysaccharide intercellular adhesion (PIA) (Vuong et al. 2004), an exopolysaccharide that is chemically very similar to PGA (Wang et al. 2004). This assay takes advantage of the fact that $E$. coli PGA crossreacts with the anti-PIA antibody (Cerca et al. 2007). Cultures of a $\Delta a b g R-y d a L$ strain carrying the vector control, pBR-McaS, pBR-McaS-3, or pBRMcaS-8 were grown in colonization factor antigen (CFA) medium in the presence of $100 \mu \mathrm{M}$ IPTG to induce McaS expression. Extracts of these cultures were spotted on membranes, which were then probed with the anti-PIA antiserum. As shown in Figure 6B, PGA levels were elevated in the strain carrying $\mathrm{pBR}-\mathrm{McaS}$ in a manner that is dependent on pgaA. In addition, even higher levels of PGA were detected for the pBR-McaS-3 strain, while the pBR-McaS- 8 strain had PGA levels comparable with the vector control strain. Taken together, the results from the Congo red plates and the PGA immunoblots indicate that McaS functions to increase PGA production in vivo.

\section{McaS sequestration of CsrA impacts biofilm formation}

While the Congo red and immunoblot assays demonstrated McaS-dependent activation of $p g a A$ results in increased synthesis and export of PGA, all of the effects of the wildtype and mutant derivatives were examined for McaS expressed from a multicopy plasmid, albeit at relatively low levels. To test whether CsrA binding to chromosomally expressed McaS impacted cell physiology, especially in the context of other CsrA-binding sRNAs such as CsrB, we examined biofilm formation under conditions where it was strongly dependent on pgaA expression (Thomason et al. 2012). We generated two strains in which the chromosomal copy of mcaS was replaced with the mcaS-3 and mcas-8 alleles. We examined pgaA-dependent biofilm formation in these backgrounds as well as in mcas and $\operatorname{csr} B$ mutant backgrounds for cells grown in CFA medium. As shown in Figure 6C and seen previously (Thomason et al. 2012), biofilm formation was reduced in the $\Delta a b g R$ $y d a L$ strain compared with the wild-type strain. The McaS-3 mutant that binds CsrA with higher affinity than wild-type McaS also showed wild-type levels of biofilm formation, while the McaS-8 mutant compromised for CsrA binding showed levels similar to the $\Delta a b g R-y d a L$ strain. These results indicate that functional CsrA-binding sites within the McaS sRNA are required for biofilm formation in CFA medium. Interestingly, the $\Delta \operatorname{csr} B$ mutant showed wildtype levels of biofilm formation, suggesting the CsrB RNA does not play a significant role in derepressing the pgaABCD operon under these growth conditions (Fig. $6 \mathrm{C)}$, although we note that it is possible that the increase in CsrC RNA levels seen below might partially compensate for the lack of CsrB.

\section{McaS levels are higher than CsrB levels under some growth conditions}

A possible explanation for the differential effects of McaS and CsrB on biofilm formation is differences in the 


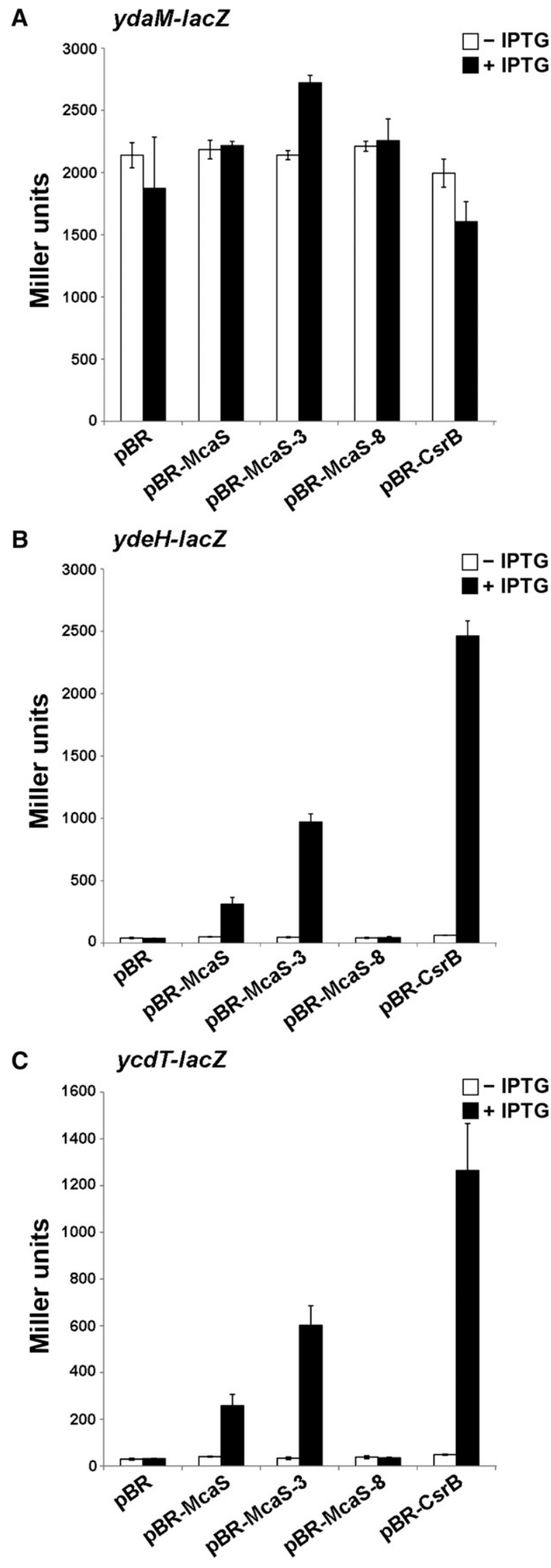

expression of the two sRNAs. While McaS and CsrB showed mostly overlapping patterns of expression in early stages of growth in LB and CFA media, a clear difference was observed after long-term growth in LB and CFA media (Fig. 7; Supplemental Fig. S7; data not shown). McaS was still detected, but very little CsrB was present after $24 \mathrm{~h}$ of growth, indicating that expression of CsrB is lost as the cells enter late stationary phase in CFA medium. This difference likely contributes to the differential effects of the two deletions on biofilm formation. The levels of CsrC throughout growth in CFA medium showed a pattern similar to CsrB, with very little CsrC detected at $24 \mathrm{~h}$.

We also examined the levels of McaS, CsrB, and CsrC in various deletion backgrounds. Notably, McaS levels were similar to wild-type levels in the csrA ::kan mutant background, while CsrB and CsrC levels were significantly reduced (Fig. 7). This is consistent with CsrA indirectly affecting expression of both $\mathrm{CsrB}$ and $\mathrm{CsrC}$ (Weilbacher et al. 2003) but not affecting the expression or stability of McaS. CsrC levels were not affected in the mcaS deletion strain but were slightly increased in the $\operatorname{csr} B$ deletion strain, consistent with previous reports (Weilbacher et al. 2003). CsrB levels also were not affected in the mcas deletion strain. These results argue for regulation of McaS that is independent of $\mathrm{CsrB}$ and $\mathrm{CsrC}$.

\section{Discussion}

In this study, we provide the first evidence that a regulatory sRNA can act through two different mechanisms to affect translation: base-pairing and sequestration of the global post-transcriptional regulator CsrA. We previously showed that McaS uses discrete regions of its stem-loop structures to directly base-pair with and repress synthesis of $\operatorname{CsgD}$, the master regulator of curli biogenesis, and activate synthesis of FlhD, the master regulator of flagellar synthesis (Jørgensen et al. 2012; Thomason et al. 2012). Here we show that McaS-mediated activation of exopolysaccharide PGA synthesis does not rely on basepairing to the $5^{\prime}$ UTR of the pgaABCD mRNA. Instead, we discovered that McaS binds strongly to CsrA and that McaS sequestration of this RNA-binding protein leads to increased expression of $p g a A$ as well as ydeH and $y c d T$ encoding two diguanylate cyclases.

\section{McaS effects on biofilm formation}

By modulating which cell surface structures are expressed under different growth conditions, the combined regulatory effects of McaS have consequences for biofilm formation. We propose that as cells enter late exponential phase, McaS activation of FlhD translation leads to

Figure 5. McaS activation of ydeH-lacZ and ycdT-lac $Z$ expression. The reporter strains PM1205 $\Delta a b g R$-ydaL ydaM-lacZ $(A)$, PM1205 $\Delta a b g R$-ydaL ydeH-lacZ (B), and PM1205 $\Delta a b g R-y d a L$ ycdT-lacZ $(C)$ were transformed with the control vector, pBRMcaS, plasmids expressing McaS mutant derivatives, and pBRCsrB. $\beta$-Galactosidase activity was assayed as in Figure 1. 
A

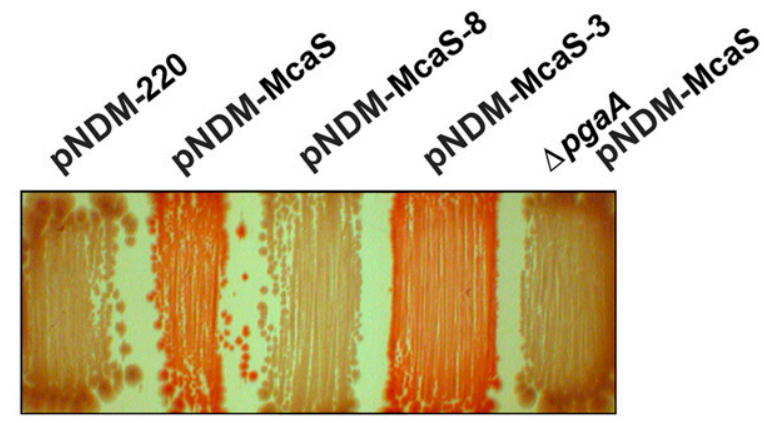

B
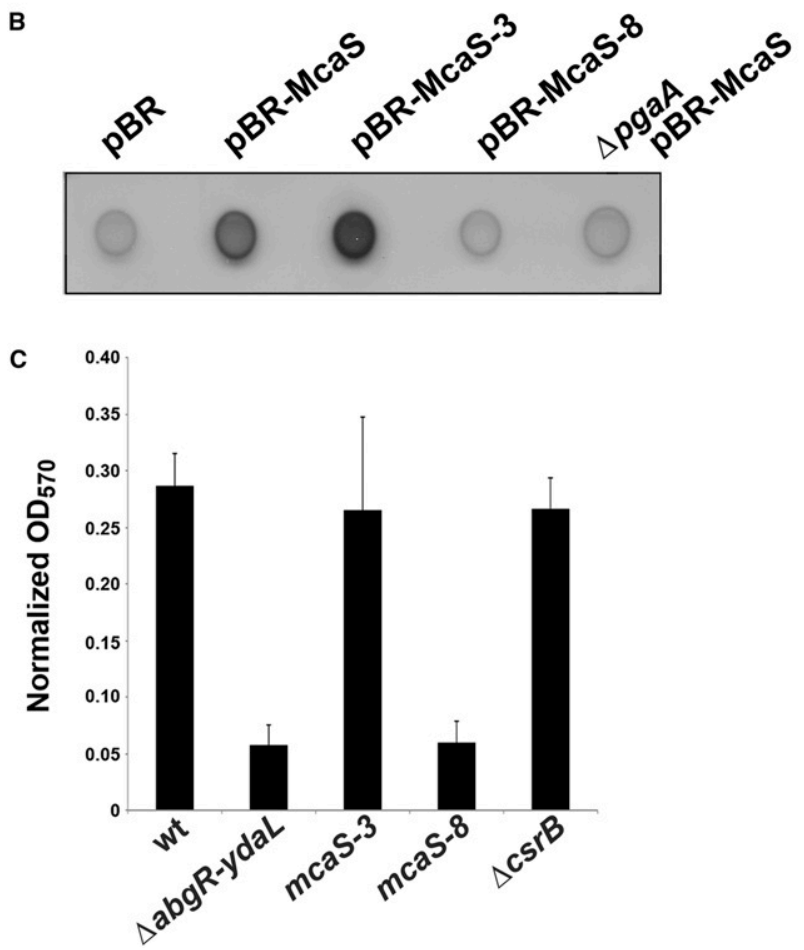

Figure 6. PGA synthesis and biofilm formation with McaS mutants. (A) The MG1655 $\Delta$ mcas $\Delta$ rpoS strain carrying either pNDM-McaS, pNDM-McaS-8, or pNDM-McaS-3 and its $\Delta p g a A$ derivative harboring pNDM-McaS were grown on Congo red indicator plates with $5 \mu \mathrm{M}$ IPTG to assay PGA production. (B) NM525 $\Delta a b g R$-ydaL carrying pBR, pBR-McaS, pBR-McaS-3, or pBR-McaS-8 and NM525 $\Delta a b g R-y d a L \Delta p g a A:: c a t$ carrying pBRMcaS were grown for $24 \mathrm{~h}$ in CFA medium with $100 \mu \mathrm{M}$ IPTG at $37^{\circ} \mathrm{C}$. Cell lysates were assayed by immunoblot analysis using a 1:5000 dilution of anti-PIA antibody. $(C)$ Five independent cultures of wild-type MG1655, the isogenic $\triangle a b g R-y d a L$ mutant lacking chromosomal mcaS, the chromosomal MG1655 mcaS::mcaS-3 and MG1655 mcaS::mcaS-8 mutants, and the isogenic $\Delta$ csr $B:$ :kan mutant were grown in CFA medium for 24 $\mathrm{h}$ at $37^{\circ} \mathrm{C}$ in a $96-$ well microtiter plate. Biofilm formation was determined by crystal violet staining, measuring absorbance at $\mathrm{OD}_{570}$, and normalizing by $\mathrm{OD}_{600}$. Images in $A-C$ are representative of at least two independent experiments.

increased motility. While this is somewhat counterintuitive at a time of waning resources given the cost of flagellar synthesis and operation, increased motility may prove advantageous if it allows the bacterium to locate additional nutrients. Subsequently, as cells transition into stationary phase, McaS accumulates to levels that lead to CsrA sequestration, increased c-di-GMP levels, and PGA capsule production through increased ycdT, $y d e H$, and pgaABCD translation, resulting in more permanent attachment and biofilm formation. Given that $E$. coli biofilm formation has been documented to require CsgD and curli fibers, it seems contradictory that McaS represses CsgD translation. However, curli-mediated biofilm formation generally occurs at temperatures $<30^{\circ} \mathrm{C}$, while PGA-dependent biofilm formation is reported to predominate at $37^{\circ} \mathrm{C}$ (Cerca and Jefferson 2008). Thus, McaS expression may play a role in modulating the balance between curli-mediated and PGA-dependent biofilm formation. It is also clear that cells within a biofilm are heterogeneous; some express curli filaments and others express flagella, depending on the location of the cell within the biofilm structure (Serra et al. 2013). We hypothesize that cells residing in different microenvironments within the biofilm may have varying levels of McaS, resulting in varying levels of PGA, curli, and flagellar production. Further studies are needed to better understand the temporal and spatial expression of McaS within the biofilm substructure as well as more fully elucidate how McaS is integrated into the complex regulatory network controlling different stages of biofilm formation under different growth conditions.

\section{Two CsrA-binding sites on McaS}

Copurification and in vitro mobility shift experiments showed that CsrA directly binds to the McaS RNA. An examination of McaS sequences showed the presence of conserved GGA motifs within the $5^{\prime}$ and central stemloops (Fig. 2A; Supplemental Fig. S2), and mutational analysis indeed revealed that these two GGA sequences are important for CsrA binding, as point mutations in

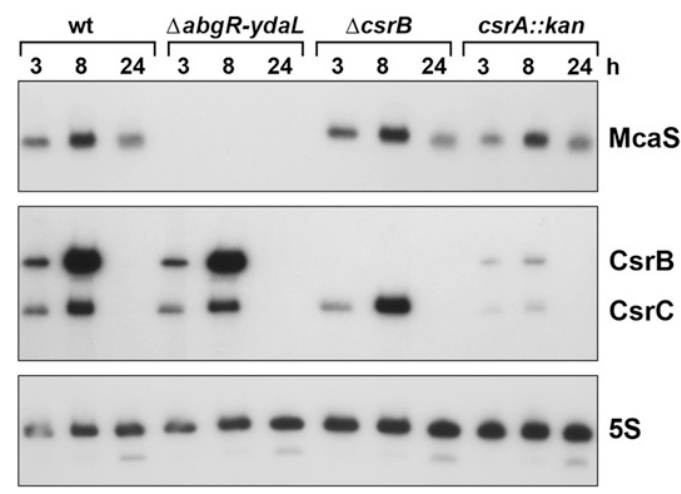

Figure 7. McaS, CsrB, and CsrC RNA levels. Cultures of wildtype MG1655, the isogenic $\triangle a b g R$-ydaL mutant lacking chromosomal mcaS, and $\Delta \operatorname{csr} B:: k a n$, and $\operatorname{csr} A::$ kan mutant strains were grown in CFA medium for $24 \mathrm{~h}$ at $37^{\circ} \mathrm{C}$. At the indicated times, samples were collected, and RNA was extracted for Northern analysis. Blots were probed with ${ }^{32} \mathrm{P}$-labeled oligonucleotides specific for $\mathrm{McaS}, \mathrm{CsrB}, \mathrm{CsrC}$, and $5 \mathrm{~S}$ as a loading control. Quantification of the RNA levels in the wild-type strain is given in Supplemental Figure S7. 
these sequences eliminate $p g a A-l a c Z$ activation in the wild-type context (McaS-8 and McaS-11). Interestingly, however, the mutation in the $5^{\prime}$ stem-loop did not significantly diminish regulation in the context of the nucleotide changes predicted to destabilize the second stem-loop (McaS-10). In addition, the McaS-3 mutant carrying only the destabilized stem-loop had significantly elevated $p g a A-l a c Z$ activity and CsrA binding. Both the McaS-3 and McaS-10 mutants gave rise to the slower-migrating band at lower CsrA concentrations than wild-type McaS.

Based on these findings, we propose that for wild-type McaS, the CsrA dimer first binds to the GGA motif located in the 5' stem-loop, increasing the local CsrA concentration and inducing a change in the McaS conformation. This conformational change facilitates access to the central stem-loop GGA that is then bound by the second half of the CsrA dimer. The nucleotide spacing between the $5^{\prime}$ and central stem-loops is $\sim 23 \mathrm{nt}$, consistent with optimal spacing for a single CsrA dimer to bridge two sites within a single target molecule (Mercante et al. 2009). If the $5^{\prime}$ stem-loop motif is mutated (McaS-2 and McaS-8), the initial binding and conformational change no longer occurs. However, this step can be circumvented if the second stem is destabilized (McaS-10). Additional mutations indicate that, in this destabilized context, initial binding to the site in the central stem-loop is followed by binding to the less conserved GGA motif located between the $5^{\prime}$ and central stem-loops (Supplemental Fig. S8). We suggest that the faster-migrating and slower-migrating bands in the mobility shift assays correspond to the initial and altered conformations of McaS but cannot exclude the possibility that the slowermigrating band consists of multiple CsrA molecules binding to a single McaS or nonspecific CsrA-CsrA interactions, as was seen for other CsrA gel shift assays (Baker et al. 2002).

An examination of the sequences of other known Hfqbinding sRNAs revealed that a number of them also contain potential CsrA-binding sites, sometimes multiple sites, although some of these sequences are likely to be sequestered in secondary structures. GcvB, which has two GGA motifs, was previously reported to copurify with CsrA (Edwards et al. 2011). However, we saw significantly less copurification of GcvB than McaS, and high levels of GcvB did not activate pgaA (Fig. 2C). In addition, neither GcvB nor RprA, which has one GGA motif, was able to bind to purified CsrA in gel shift mobility assays (Fig. 4C). These results indicate that the association between GcvB and CsrA is most likely indirect, perhaps through a common mRNA molecule. What distinguishes the GGA sequences on McaS, which lead to productive CsrA binding, from potential binding sites on other base-pairing sRNAs is not yet clear.

\section{Dual CsrA and Hfq binding to McaS}

McaS, like other known base-pairing sRNAs, requires Hfq for stability and is coimmunoprecipitated with Hfq (Jørgensen et al. 2012; Thomason et al. 2012). This raises the question of whether CsrA and Hfq are binding different populations of McaS or both RNA-binding proteins are associating with McaS simultaneously. Hfq has been shown to bind to U-rich sequences internal to some sRNAs as well as to the poly (U) tail of the Rho-independent terminator present in the $3^{\prime}$ end of many sRNAs (Otaka et al. 2011), so conceivably, the CsrAand Hfq-binding sites on McaS are not overlapping. Consistent with this model, Hfq and CsrA were observed to simultaneously bind McaS, but not RprA, in vitro (Supplemental Fig. S9). Unlike in the $\Delta h f q$ mutant, the levels of McaS are not significantly decreased in the csrA::kan mutant strain (Fig. 7), indicating that McaS requires Hfq but not CsrA for stability.

\section{Competition between CsrB and McaS for CsrA binding}

As already noted, the activity of CsrA is also modulated by two Hfq-independent sRNAs: CsrB and CsrC. CsrB has 18 GGA motifs and is able to bind nine molecules of CsrA (one homodimer for every two CsrB-binding sites) (Liu et al. 1997), while CsrC has nine GGA motifs and shows lower affinity for CsrA (Weilbacher et al. 2003). The large number of CsrA-binding sites on CsrB and the relative abundance of the sRNA under multiple growth conditions raise the question of whether McaS could ever compete with CsrB for CsrA binding. For cells grown in medium supplemented with glucose, it is estimated that only one-third of available CsrA present in the cell is bound by CsrB, with a much smaller percentage bound by CsrC (Gudapaty et al. 2001; Weilbacher et al. 2003). This would leave two-thirds of the cellular CsrA available for binding target mRNAs. In addition, the relative levels and stabilities of CsrB, CsrC, and McaS might be different under other growth conditions. Coherent with this suggestion, our Northern analysis indicates that while expression of $\mathrm{McaS}, \mathrm{CsrB}$, and $\mathrm{CsrC}$ all increase as the cells enter stationary phase in CFA and LB media, CsrB and CsrC levels are significantly diminished later in stationary phase $(\sim 24 \mathrm{~h})$. Given the availability of free CsrA molecules and differential CsrB, CsrC, and McaS expression, it seems plausible that McaS could modulate the activity of an unbound pool of CsrA under certain growth conditions.

The results of the biofilm assay support this notion (Fig. 6C). Chromosomal levels of McaS are required for biofilm formation mediated through titration of CsrA and activation of $p g a A$, as both the deletion of mcaS and the McaS-8 mutant defective for CsrA binding show reduced biofilm formation. McaS thus provides a mechanism for the control of biofilm formation that is separate from the CsrA-CsrB-CsrC autoregulatory loop, thereby adding another level of regulation to the CsrA network and increasing the complexity of the control of biofilm formation in E. coli.

\section{Dual-function RNAs}

Over the past decade, it has become clear that the transcriptional output of the genome is much more complex than initially anticipated and that "noncoding" 
transcripts act as important regulatory elements in biological processes in all organisms from bacteria to humans (for review, see Taft et al. 2010; Storz et al. 2011). While these regulatory RNAs are often grouped into separate categories based on initially identified functions, as we showed for McaS, these delineations are becoming blurred with the increasing discovery of regulatory RNA molecules with more than one intrinsic function (for review, see Ulveling et al. 2011; Vanderpool et al. 2011). Several RNAs originally classified as "noncoding" RNAs have been shown to transmit both regulatory and protein-coding information. For example, the sugar phosphate stressinduced E. coli SgrS RNA was first shown to repress expression of the PtsG sugar phosphate transporter by basepairing and then was later found to also encode a small protein, which inhibits sugar phosphate transport (Wadler and Vanderpool 2007). Conversely, RNAs regarded as strictly protein-coding have been found to act as regulatory molecules. In E. coli and Salmonella, an mRNA that possesses a sequence capable of mimicking a base-pairing target site regulates the levels of the MicM/ChiX sRNA, which is constitutively transcribed (Figueroa-Bossi et al. 2009; Overgaard et al. 2009). Thus, expression of this decoy or trap mRNA relieves MicM/ChiX-mediated repression of the authentic target mRNAs. This mRNA-based regulation is reminiscent of target mimicry for regulation of microRNA (miRNA) activity in plants by noncoding transcripts (Franco-Zorrilla et al. 2007). Many computationally identified miRNA target mRNAs, including transcripts expressed from pseudogenes in mammalian systems, have similarly been proposed to actually be competitive inhibitors of miRNA function (known as miRNA sponges) (Seitz 2009; Ebert and Sharp 2010; Poliseno et al. 2010).

The sRNA McaS represents a new class of dual-function sRNAs: those that can act through base-pairing and through protein titration. Our findings beg the question of whether other Hfq-dependent, base-pairing sRNAs could also act as protein titrators or whether other Hfqindependent, protein-titrating sRNAs have the ability to act by base-pairing mechanisms. We expect that further study of McaS and additional sRNAs will reveal even more overlap between the previously distinct classes of sRNAs and regulatory networks.

\section{Materials and methods}

\section{Bacterial strains and plasmids}

The bacterial strains used in the study were derived from $E$. coli K-12 MG1655 or SØ928 and are listed together with the plasmids used in Supplemental Table S1. Strain and plasmid constructions are described in detail in the Supplemental Material. Gene knockouts and fusions were constructed using $\lambda$ red-mediated recombination (Datsenko and Wanner 2000; Court et al. 2003) using oligonucleotides listed in Supplemental Table S2. Mutant loci, including the TR1-5 csrA::kan (Romeo et al. 1993), rpoS359::Tn10 (Lange and Hengge-Aronis 1991), $\triangle a b g R-y d a L$ (Thomason et al. 2012), and $\Delta c s r B:: k a n$ (Hobbs et al. 2010) alleles, were moved into the relevant strain backgrounds by P1 transduction. Where indicated, antibiotic resistance markers were removed using pCP20 /Cherepanov and Wackernagel
1995). The ydeH-lacZ, ydaM-lacZ, ycdT-lacZ, glgC-lacZ, and various pgaA-lac $Z$ truncation fusions were constructed by inserting the $5^{\prime}$ UTR through the 10th codon of the ORF between the $\mathrm{P}_{\mathrm{BAD}}$ promoter and lac $Z$ on the chromosome (Mandin and Gottesman 2009). The mcaS chromosomal mutant strains were constructed by inserting a cat-sacB cassette into the mcaS locus and then replacing this cassette with a fragment encompassing the mutant allele by recombineering and counterselection on M63 minimal glycerol sucrose plates at $30^{\circ} \mathrm{C}$.

\section{Growth conditions}

Cells were cultivated aerobically at $37^{\circ} \mathrm{C}$ in $\mathrm{LB}$ medium $(10 \mathrm{~g}$ of tryptone, $5 \mathrm{~g}$ of yeast extract, $10 \mathrm{~g}$ of $\mathrm{NaCl}$ per liter) or CFA medium ( $10 \mathrm{~g}$ of casamino acids, $1.5 \mathrm{~g}$ of yeast extract, $50 \mathrm{mg}$ of $\mathrm{MgSO}_{4}, 5 \mathrm{mg}$ of $\mathrm{MnCl}_{2}$ per liter). Expression of PGA was monitored on Congo red agar plates (10 g of bacto-tryptone, $5 \mathrm{~g}$ of yeast extract, $10 \mathrm{~g}$ of $\mathrm{NaCl}$ per liter, $40 \mu \mathrm{g} / \mathrm{mL}$ Congo red, 10 $\mu \mathrm{g} / \mathrm{mL}$ Coomassie brilliant blue G). The plates were incubated for $24 \mathrm{~h}$ at $37^{\circ} \mathrm{C}$. IPTG was added at a final concentration of 1 $\mathrm{mM}$ unless otherwise indicated. Antibiotics were added at 100 $\mu \mathrm{g} / \mathrm{mL}$ ampicillin (amp), $30 \mu \mathrm{g} / \mathrm{mL}$ kanamycin (kan), $12.5 \mu \mathrm{g} / \mathrm{mL}$ tetracycline (tet), or $25 \mu \mathrm{g} / \mathrm{mL}$ chloramphenicol (cat).

\section{$\beta$-Galactosidase assays}

$\beta$-Galactosidase activity was assayed and calculated as described (Thomason et al. 2012).

\section{Copurification assay}

Cells were grown in $100 \mathrm{~mL}$ of $\mathrm{LB}$ medium to $\mathrm{OD}_{450} \sim 3.0$, harvested, and washed with $100 \mathrm{~mL}$ of ice-cold immunoprecipitation buffer $(150 \mathrm{mM} \mathrm{KCl}, 100 \mathrm{mM}$ Tris- $\mathrm{HCl}$ at $\mathrm{pH} 7.5,1 \mathrm{mM}$ $\mathrm{MgCl}_{2}, 1 \mathrm{mM} \mathrm{CaCl}_{2}$ ). The cell pellets were resuspended in $10 \mathrm{~mL}$ of ice-cold immunoprecipitation buffer supplemented with 10 $\mu \mathrm{L}$ of protease inhibitor cocktail (Calbiochem) and $10 \mu \mathrm{L}$ of antiRNase (Ambion). Cells were disrupted in a french press and centrifuged at $12,000 \mathrm{~g}$ for $1 \mathrm{~h}$ at $4^{\circ} \mathrm{C}$. One milliliter of the supernatant was incubated with $50 \mu \mathrm{L}$ of anti-Flag M2-agarose suspension (Sigma) for $1 \mathrm{~h}$ at $4^{\circ} \mathrm{C}$. The mixture was filtered using a mini chromatography column (Bio-Rad). The filtrate was collected (unbound fraction [UB]), and the column was washed once with $300 \mu \mathrm{L}$ of immunoprecipitation buffer (wash fraction [W]) and once with $1 \mathrm{~mL}$ of immunoprecipitation buffer. Proteins bound to the anti-Flag beads were eluted twice with $300 \mu \mathrm{L}$ of $1 \mathrm{M}$ arginine buffer ( $\mathrm{pH} 3.5$; bound fraction 1 and 2 [B1 and $\mathrm{B} 2]$ ). The samples eluted with the arginine buffer were promptly neutralized with $1 \mathrm{M}$ Tris buffer ( $\mathrm{pH}$ 8.0). The unbound fractions $(300 \mu \mathrm{L})$, wash fractions $(300 \mu \mathrm{L})$, and bound fractions $(300 \mu \mathrm{L})$ as well as the protein-stripped beads (S) resuspended in $300 \mu \mathrm{L}$ of nuclease-free water were treated with phenol. The nucleic acids were precipitated and washed with ethanol. The precipitates from unbound fractions were dissolved in $20 \mu \mathrm{L}$ of water, the RNA concentrations were estimated by absorption at $260 \mathrm{~nm}$, and a volume equivalent to $10 \mu \mathrm{g}$ was dissolved in $14 \mu \mathrm{L}$ of formamide loading dye. Precipitates from the remaining fractions (W, BI, BII, and S) were dissolved in $14 \mu \mathrm{L}$ of loading buffer (formamide), and $12 \mu \mathrm{L}$ of all RNA samples was subjected to Northern analysis.

\section{Northern analysis}

Total RNA was extracted, and Northern analysis was carried out as described (Overgaard et al. 2009; Thomason et al. 2012). 


\section{Purification of RNA-free CsrA protein}

Flag-tagged CsrA protein was expressed from MG1655 csrA$3 x$ Flag carrying the pBAD33 derivative pBAD-csr $A-3 x$ Flag. The strain was grown in $\mathrm{LB}$ medium at $37^{\circ} \mathrm{C}$ to $\mathrm{OD}_{600} \sim 1.0$. At this point, CsrA-Flag expression from the vector was induced by the addition of $10 \mathrm{mM}$ arabinose. After $3 \mathrm{~h}$, the cells were pelleted at $4^{\circ} \mathrm{C}$, washed, and resuspended in lysis buffer $(50 \mathrm{mM}$ Tris $\mathrm{HCl}$ at $\mathrm{pH} 7.4,150 \mathrm{mM} \mathrm{NaCl}, 1 \mathrm{mM}$ EDTA, $1 \%$ Triton X-100). The cells were disrupted using a french press and then subjected to centrifugation at $15,000 \mathrm{~g}$ for $45 \mathrm{~min}$ at $4^{\circ} \mathrm{C}$. The cleared lysate was mixed with $2 \mathrm{~mL}$ of $\alpha$-Flag M2 magnetic beads (Sigma) prewashed in TBS buffer $(50 \mathrm{mM}$ Tris $\mathrm{HCl}, 150 \mathrm{mM} \mathrm{NaCl}$ at $\mathrm{pH}$ 7.4) and incubated on a roller shaker for $2 \mathrm{~h}$ at $4^{\circ} \mathrm{C}$. The magnetic beads were washed in wash buffer $(50 \mathrm{mM}$ Tris $\mathrm{HCl}$ at $\mathrm{pH}$ 7.4, $1 \mathrm{M} \mathrm{NaCl}, 1 \mathrm{mM}$ EDTA, $1 \%$ Triton X-100) before incubation with $10 \mu \mathrm{g} / \mathrm{mL}$ RNase A (Sigma) for $1 \mathrm{~h}$ at $37^{\circ} \mathrm{C}$. The beads were washed several times in wash buffer before the CsrA-Flag protein was eluted with $1 \mathrm{M}$ arginine (pH 3.0) (Futatsumori-Sugai et al. 2009). The eluted protein fraction was immediately neutralized with $2 \mathrm{M}$ Tris ( $\mathrm{pH}$ 8.0) before the protein was concentrated and dialyzed overnight at $4^{\circ} \mathrm{C}$ against two changes of $10 \mathrm{mM}$ Trisacetate ( $\mathrm{pH} 8.0)$.

\section{In vitro synthesis and labeling of RNA}

The McaS, RprA, GcvB, and CsrB RNAs were prepared by in vitro transcription (MegaScript, Ambion) with T7 RNA polymerase using $1 \mu \mathrm{g}$ of PCR template as the input DNA. Template DNA for T7 transcription was amplified from SØ928 chromosomal DNA using the primer sets listed in Supplemental Table S2. Each in vitro transcript was DNase I-treated before PAGE separation on a $6 \%$ polyacrylamide-7 $\mathrm{M}$ urea gel in $0.5 \times$ TBE. The RNAs were extracted from the gel and quantified on a NanoDrop 1000 (Thermo Scientific). If required, the transcripts were radiolabeled at the $5^{\prime}$ end with $\gamma^{-}{ }^{32} \mathrm{P}$-ATP using the KinaseMax kit (Ambion).

\section{Electrophoretic mobility shift assays}

Mobility shift assays were conducted by incubating radiolabeled RNA ( $1 \mathrm{nM}$ ) with the indicated concentrations of unlabeled RNA or purified CsrA protein in a $10-\mu \mathrm{L}$ reaction containing $1 \times$ binding buffer ( $20 \mathrm{mM}$ Tris at $\mathrm{pH} 8,150 \mathrm{mM} \mathrm{KCl}, 1 \mathrm{mM}$ DTT). Reactions were incubated for $5 \mathrm{~min}$ at $37^{\circ} \mathrm{C}$, whereupon $3 \mu \mathrm{L}$ of $5 \times$ loading buffer $(50 \%$ glycerol, $0.2 \%$ bromophenol blue, $2.5 \times$ $\mathrm{TBE}$ ) was added, and reactions were resolved on a nondenaturing $5 \%$ polyacrylamide gel in $0.5 \times \mathrm{TBE}$ at $4^{\circ} \mathrm{C}$. Gels were dried and exposed to BioMax XAR film (Kodak) or phosphor screen for PhosphorImager analysis (GE Healthcare).

\section{Assay of PGA levels}

Immunoblot assays to detect PGA levels were performed as described with minor changes (Cerca et al. 2007). Cultures were grown in CFA for $24 \mathrm{~h}$ in the presence of $100 \mu \mathrm{M}$ IPTG. The entire $5-\mathrm{mL}$ culture was centrifuged, the supernatant was removed, and cells were lysed by resuspending in $300 \mu \mathrm{L}$ of $0.5 \mathrm{M}$ EDTA followed by incubation for $5 \mathrm{~min}$ at $99^{\circ} \mathrm{C}$. The cell debris was removed by spinning at $10,500 \mathrm{~g}$ for $6 \mathrm{~min}$. The supernatant was removed, and $100 \mu \mathrm{L}$ was incubated with $10 \mu \mathrm{L}$ of $20 \mathrm{mg} / \mathrm{mL}$ Proteinase $\mathrm{K}$ (Gibco) for $1 \mathrm{~h}$ at $60^{\circ} \mathrm{C}$ followed by $30 \mathrm{~min}$ at $80^{\circ} \mathrm{C}$ to inactivate the Proteinase K. Aliquots $(25 \mu \mathrm{L})$ of the treated samples were spotted on nitrocellulose membrane and allowed to air dry for $5 \mathrm{~h}$. The membrane was washed briefly with $1 \times$ TBST ( $1 \times$ TBS, $0.1 \%$ Tween 20 ), blocked for $1 \mathrm{~h}$ in $5 \%$ milk- $1 \times$
TBST, and then incubated overnight at room temperature in a 1:5000 dilution of rabbit anti-PIA antibody in $5 \%$ milk-1X TBST. The membrane was washed briefly three times with $1 \times$ TBST and then incubated with a 1:10,000 dilution of HRP antirabbit IgG antibody (Amersham) for $1 \mathrm{~h}$ in $5 \%$ milk-1× TBST. The membrane was washed three additional times with $1 \times$ TBST and then developed using Amersham ECL Western blot detection reagent (GE Healthcare) and exposed to Kodak Blue-XB film.

\section{Biofilm assay}

Biofilm growth assays were performed as described $(\mathrm{Wu}$ and Outten 2009; Thomason et al. 2012).

\section{Acknowledgments}

We thank T. Romeo for the csrA ::kan mutant strain, M. Otto for the anti-PIA antiserum, and S. Gottesman, N. De Lay, and members of the Storz laboratory for comments on the manuscript. Work in the G.S. laboratory was supported by the Intramural Program of the Eunice Kennedy Shriver National Institute of Child Health and Human Development. Work in the P.V.-H. laboratory was supported by The Danish Council for Independent Research (FNU). M.G.J. was supported by the Lundbeck Foundation and Villum Foundation.

\section{References}

Amini S, Goodarzi H, Tavazoie S. 2009. Genetic dissection of an exogenously induced biofilm in laboratory and clinical isolates of E. coli. PLoS Pathog 5: e1000432.

Baker CS, Morozov I, Suzuki K, Romeo T, Babitzke P. 2002. CsrA regulates glycogen biosynthesis by preventing translation of $g \operatorname{lgC}$ in Escherichia coli. Mol Microbiol 44: 15991610.

Baker CS, Eöry LA, Yakhnin H, Mercante J, Romeo T, Babitzke P. 2007. CsrA inhibits translation initiation of Escherichia coli $h f q$ by binding to a single site overlapping the ShineDalgarno sequence. I Bacteriol 189: 5472-5481.

Boehm A, Steiner S, Zaehringer F, Casanova A, Hamburger F, Ritz D, Keck W, Ackermann M, Schirmer T, Jenal U. 2009. Second messenger signalling governs Escherichia coli biofilm induction upon ribosomal stress. Mol Microbiol 72: 1500-1516.

Cerca N, Jefferson KK. 2008. Effect of growth conditions on poly-N-acetylglucosamine expression and biofilm formation in Escherichia coli. FEMS Microbiol Lett 283: 36-41.

Cerca N, Maira-Litran T, Jefferson KK, Grout M, Goldmann DA, Pier GB. 2007. Protection against Escherichia coli infection by antibody to the Staphylococcus aureus poly-N-acetylglucosamine surface polysaccharide. Proc Natl Acad Sci 104: 7528-7533.

Cherepanov PP, Wackernagel W. 1995. Gene disruption in Escherichia coli: TcR and KmR cassettes with the option of Flp-catalyzed excision of the antibiotic-resistance determinant. Gene 158: 9-14.

Court DL, Swaminathan S, Yu D, Wilson H, Baker T, Bubunenko M, Sawitzke J, Sharan SK. 2003. Mini- $\lambda$ : A tractable system for chromosome and BAC engineering. Gene 315: 63-69.

Datsenko KA, Wanner BL. 2000. One-step inactivation of chromosomal genes in Escherichia coli K-12 using PCR products. Proc Natl Acad Sci 97: 6640-6645.

De Lay N, Gottesman S. 2012. A complex network of small noncoding RNAs regulate motility in Escherichia coli. Mol Microbiol 86: 524-538. 
Dubey AK, Baker CS, Romeo T, Babitzke P. 2005. RNA sequence and secondary structure participate in high-affinity CsrA-RNA interaction. RNA 11: 1579-1587.

Ebert MS, Sharp PA. 2010. Emerging roles for natural microRNA sponges. Curr Biol 20: R858-R861.

Edwards AN, Patterson-Fortin LM, Vakulskas CA, Mercante JW, Potrykus K, Vinella D, Camacho MI, Fields JA, Thompson SA, Georgellis D, et al. 2011. Circuitry linking the Csr and stringent response global regulatory systems. Mol Microbiol 80: $1561-1580$.

Figueroa-Bossi N, Valentini M, Malleret L, Fiorini F, Bossi L. 2009. Caught at its own game: Regulatory small RNA inactivated by an inducible transcript mimicking its target. Genes Dev 23: 2004-2015.

Flemming HC, Wingender J. 2010. The biofilm matrix. Nat ReV Microbiol 8: 623-633.

Franco-Zorrilla JM, Valli A, Todesco M, Mateos I, Puga MI, Rubio-Somoza I, Leyva A, Weigel D, García JA, Paz-Ares J. 2007. Target mimicry provides a new mechanism for regulation of microRNA activity. Nat Genet 39: 10331037.

Futatsumori-Sugai M, Abe R, Watanabe $M$, Kudou M, Yamamoto T, Ejima D, Arakawa T, Tsumoto K. 2009. Utilization of Argelution method for Flag-tag based chromatography. Protein Expr Purif 67: 148-155.

Gudapaty S, Suzuki K, Wang X, Babitzke P, Romeo T. 2001. Regulatory interactions of Csr components: The RNA binding protein CsrA activates csrB transcription in Escherichia coli. J Bacteriol 183: 6017-6027.

Hammar M, Arnqvist A, Bian Z, Olsén A, Normark S. 1995. Expression of two csg operons is required for production of fibronectin- and congo red-binding curli polymers in Escherichia coli K-12. Mol Microbiol 18: 661-670.

Hobbs EC, Astarita JL, Storz G. 2010. Small RNAs and small proteins involved in resistance to cell envelope stress and acid shock in Escherichia coli: Analysis of a bar-coded mutant collection. J Bacteriol 192: 59-67.

Holmqvist E, Reimegård J, Sterk M, Grantcharova N, Römling U, Wagner EGH. 2010. Two antisense RNAs target the transcriptional regulator CsgD to inhibit curli synthesis. EMBO T 29: 1840-1850.

Izano EA, Sadovskaya I, Wang H, Vinogradov E, Ragunath C, Ramasubbu N, Jabbouri S, Perry MB, Kaplan JB. 2008. Poly$\mathrm{N}$-acetylglucosamine mediates biofilm formation and detergent resistance in Aggregatibacter actinomycetemcomitans. Microb Pathog 44: 52-60.

Jin Y, Watt RM, Danchin A, Huang JD. 2009. Use of a riboswitchcontrolled conditional hypomorphic mutation to uncover a role for the essential csrA gene in bacterial autoaggregation. I Biol Chem 284: 28738-28745.

Jonas K, Edwards AN, Simm R, Romeo T, Römling U, Melefors O. 2008. The RNA binding protein CsrA controls cyclic di-GMP metabolism by directly regulating the expression of GGDEF proteins. Mol Microbiol 70: 236-257.

Jørgensen MG, Nielsen JS, Boysen A, Franch T, Møller-Jensen J, Valentin-Hansen P. 2012. Small regulatory RNAs control the multi-cellular adhesive lifestyle of Escherichia coli. Mol Microbiol 84: 36-50.

Keseler IM, Collado-Vides J, Santos-Zavaleta A, Peralta-Gil M, Gama-Castro S, Muñiz-Rascado L, Bonavides-Martinez C, Paley S, Krummenacker M, Altman T, et al. 2011. EcoCyc: A comprehensive database of Escherichia coli biology. Nucleic Acids Res 39: D583-D590.

Lange R, Hengge-Aronis R. 1991. Identification of a central regulator of stationary-phase gene expression in Escherichia coli. Mol Microbiol 5: 49-59.
Liu MY, Gui G, Wei B, Preston JFI, Oakford L, Yüksel U, Giedroc DP, Romeo T. 1997. The RNA molecule CsrB binds to the global regulatory protein CsrA and antagonizes its activity in Escherichia coli. J Biol Chem 272: 17502-17510.

López D, Vlamakis H, Kolter R. 2010. Biofilms. Cold Spring Harb Perspect Biol 2: a000398.

Mandin P, Gottesman S. 2009. A genetic approach for finding small RNAs regulators of genes of interest identifies RybC as regulating the DpiA/DpiB two-component system. Mol Microbiol 72: 551-565.

Mercante J, Suzuki K, Cheng X, Babitzke P, Romeo T. 2006. Comprehensive alanine-scanning mutagenesis of Escherichia coli CsrA defines two subdomains of critical functional importance. I Biol Chem 281: 31832-31842.

Mercante JW, Edwards AN, Dubey AK, Babitzke P, Romeo T. 2009. Molecular geometry of CsrA (RsmA) binding to RNA and its implications for regulated expression. J Mol Biol 392: 511-528.

Mika F, Busse S, Possling A, Berkholz J, Tschowri N, Sommerfeldt N, Pruteanu M, Hengge R. 2012. Targeting of $\operatorname{csg} D$ by the small regulatory RNA RprA links stationary phase, biofilm formation and cell envelope stress in Escherichia coli. Mol Microbiol 84: 51-65.

Otaka H, Ishikawa H, Morita T, Aiba H. 2011. PolyU tail of $\rho$-independent terminator of bacterial small RNAs is essential for Hfq action. Proc Natl Acad Sci 108: 13059-13064.

Overgaard M, Johansen J, Møller-Jensen J, Valentin-Hansen P. 2009. Switching off small RNA regulation with trap-mRNA. Mol Microbiol 73: 790-800.

Pannuri A, Yakhnin H, Vakulskas CA, Edwards AN, Babitzke P, Romeo T. 2012. Translational repression of NhaR, a novel pathway for multi-tier regulation of biofilm circuitry by CsrA. J Bacteriol 194: 79-89.

Poliseno L, Salmena L, Zhang J, Carver B, Haveman WJ, Pandolfi PP. 2010. A coding-independent function of gene and pseudogene mRNAs regulates tumour biology. Nature 465: 10331038.

Romeo T, Gong M, Liu MY, Brun-Zinkernagel AM. 1993. Identification and molecular characterization of $\operatorname{csr} A$, a pleiotropic gene from Escherichia coli that affects glycogen biosynthesis, gluconeogenesis, cell size, and surface properties. J Bacteriol 175: 4744-4755.

Romeo T, Vakulskas CA, Babitzke P. 2012. Post-transcriptional regulation on a global scale: Form and function of Csr/Rsm systems. Environ Microbiol 15: 313-324.

Schubert M, Lapouge K, Duss O, Oberstrass FC, Jelesarov I, Haas D, Allain FH. 2007. Molecular basis of messenger RNA recognition by the specific bacterial repressing clamp RsmA/ CsrA. Nat Struct Mol Biol 14: 807-813.

Seitz H. 2009. Redefining microRNA targets. Curr Biol 19: 870873.

Serra DO, Richter AM, Klauck G, Mika F, Hengge R. 2013. Microanatomy at cellular resolution and spatial order of physiological differentiation in a bacterial biofilm. mBio 4: e00103-e00113.

Steiner S, Lori C, Boehm A, Jenal U. 2013. Allosteric activation of exopolysaccharide synthesis through cyclic di-GMP-stimulated protein-protein interaction. EMBO J 32: 354-368.

Storz G, Vogel J, Wassarman KM. 2011. Regulation by small RNAs in bacteria: Expanding frontiers. Mol Cell 43: 880-891.

Taft RJ, Pang KC, Mercer TR, Dinger M, Mattick JS. 2010. Noncoding RNAs: Regulators of disease. J Pathol 220: 126-139.

Thomason MK, Fontaine F, De Lay N, Storz G. 2012. A small RNA that regulates motility and biofilm formation in response to changes in nutrient availability in Escherichia coli. Mol Microbiol 84: 17-35. 
Timmermans J, Van Melderen L. 2009. Conditional essentiality of the csrA gene in Escherichia coli. J Bacteriol 191: 17221724.

Ulveling D, Francastel C, Hubé F. 2011. When one is better than two: RNA with dual functions. Biochemie 93: 633-644.

Vanderpool CK, Balasubramanian D, Lloyd CR. 2011. Dualfunction RNA regulators in bacteria. Biochimie 93: 19431949.

Vuong C, Kocianova S, Voyich JM, Yao Y, Fischer ER, DeLeo FR, Otto M. 2004. A crucial role for exopolysaccharide modification in bacterial biofilm formation, immune evasion, and virulence. J Biol Chem 279: 54881-54886.

Wadler CS, Vanderpool CK. 2007. A dual function for a bacterial small RNA: SgrS performs base pairing-dependent regulation and encodes a functional polypeptide. Proc Natl Acad Sci 104: 20454-20459.

Wang X, Preston JF 3rd, Romeo T. 2004. The pgaABCD locus of Escherichia coli promotes the synthesis of a polysaccharide adhesin required for biofilm formation. I Bacteriol 186: 2724-2734.

Wang X, Dubey AK, Suzuki K, Baker CS, Babitzke P, Romeo T. 2005. CsrA post-transcriptionally represses pgaABCD, responsible for synthesis of a biofilm polysaccharide adhesin of Escherichia coli. Mol Microbiol 56: 1648-1663.

Weilbacher T, Suzuki K, Dubey AK, Wang X, Gudapaty S, Morozov I, Baker CS, Georgellis D, Babitzke P, Romeo T. 2003. A novel sRNA component of the carbon storage regulatory system of Escherichia coli. Mol Microbiol 48: 657-670.

Wu Y, Outten FW. 2009. IscR controls iron-dependent biofilm formation in Escherichia coli by regulating type I fimbria expression. J Bacteriol 191: 1248-1257.

Yakhnin AV, Baker CS, Vakulskas CA, Yakhnin H, Berezin I, Romeo T, Babitzke P. 2013. CsrA activates flhDC expression by protecting flhDC mRNA from RNase E-mediated cleavage. Mol Microbiol 87: 851-866. 


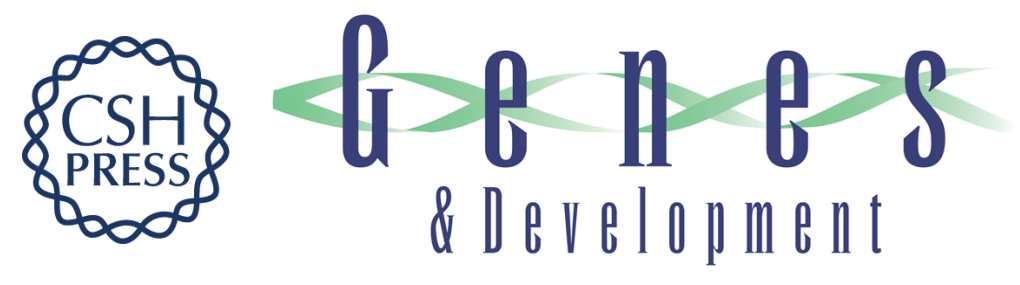

\section{Dual function of the McaS small RNA in controlling biofilm formation}

Mikkel Girke Jørgensen, Maureen K. Thomason, Johannes Havelund, et al.

Genes Dev. 2013, 27: originally published online May 10, 2013

Access the most recent version at doi:10.1101/gad.214734.113

\footnotetext{
Supplemental http://genesdev.cshlp.org/content/suppl/2013/05/02/gad.214734.113.DC1

Material

Related Content A small RNA serving both the Hfq and CsrA regulons

Erik Holmqvist and Jörg Vogel

Genes Dev. May, 2013 27: 1073-1078

References This article cites 56 articles, 19 of which can be accessed free at: http://genesdev.cshlp.org/content/27/10/1132.full.html\#ref-list-1

Articles cited in:

http://genesdev.cshlp.org/content/27/10/1132.full.html\#related-urls

License

Email Alerting
Service $\begin{aligned} & \text { Receive free email alerts when new articles cite this article - sign up in the box at the top } \\ & \text { right corner of the article or click here. }\end{aligned}$
}

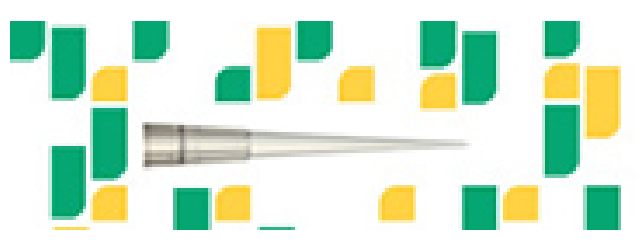

Focused on your science. 